\title{
EFL VOCABULARY LEARNING STRATEGIES USED BY SAUDI ARABIA UNIVERSITY STUDENTS
}

\author{
Sahal R. Alshammari \\ Northern Border University, Arar, Saudi Arabia \\ alshammarisahal@gmail.com
}

\begin{abstract}
Language skills depend on the meaning of words and the knowledge of the subject/context. The meanings of words that shape the true understanding of contexts are needed to experience language as a real-life activity. College students in Saudi Arabia struggle to develop desired proficiency in the English language that is required to further advance in their academic endeavours. It has been observed that even the minimum vocabulary level is far to be realised as reality, which consequently has posed a challenge for the various stakeholders to find the most effective strategies for Saudi learners. The present study tries to unfold the basic components which are needed to be in order first before considering the other related factors. In this study, a total of 85 male and female students were asked first appear for the vocabulary test, required to assess if they have achieved their desired levels. Their academic achievement in the specialised vocabulary course and their achievement in the standardised test have been compared with their strategies for language learning. The differences in the responses of the high achievers and the low achievers observed and found that high achievers give importance to all the strategies equally well, whereas the low achievers just focus on meta-cognitive and memory strategies. The results open up new dimensions for the teachers as well as the learners to choose and implement the best practices suited as per their academic and non-academic needs. Besides this, the other stakeholders like material developers, curriculum designers, educators and trainers will also have a macro picture of inside and outside of classrooms so that they could narrow down on the associated elements (motivation, learners' autonomy, socio-cultural contexts etc.)
\end{abstract}

Keywords: vocabulary; EFL learners; L1 interference; vocabulary strategies; Arab learners.

\section{Introduction}

The literature of EFL learning in Saudi Arabia and Arab countries in general shows that very little progress has been made in the teaching of English to Arab learners (Ahmed, 2010; Alrabai, 2014, 2016; Alshammari, 2016; Doushaq, 1986; Elyas \& Picard, 2010; Grami, 2010; Hashim, 1996; Mohammad \& Hazarika, 2016; Rababah, 2002). English is considered a foreign language in most of the Arab countries (e.g., Saudi Arabia) and second language in few countries like United Arab Emirates (UAE) and Qatar. This indicates that vocabulary acquisition is essential for learning a second language because learners do not have a chance to learn or use new vocabulary items outside their classrooms. Therefore, it is unexpected that L2 learners with poor vocabulary will have the desired ability to comprehend informal conversation (Ahmad, 2012; Alhaysony, 2012; Mohamed \& Mahmoud, 2014) or a written passage in their academic or nonacademic endeavours (Al-Darayseh, 2014).

One of the problems L2 learners encounter is that vocabulary acquisition is not as expected to their levels. Vocabulary learning is an accumulative process wherein students' vocabulary grows as the learners advance in their academic levels, so the students are expected to have sufficient vocabulary at the college level. Though different approaches have been suggested to teach vocabulary to L2 learners, the best means of achieving good vocabulary learning is still unclear (Schmitt, 2008, 2010). There are several variables which influence vocabulary acquisition and cause difficulties in finding the most effective method of teaching vocabulary to L2 learners. For example, it is difficult to decide how much vocabulary is to be learned and the literature does not help in this regard as the results are contradictory (Bonk, 2000; Schmitt, 2000, 2008, 2010). Moreover, the academic departments have adapted syllabi and materials which do not consider student current level of vocabulary; hence, they lack clear guidelines to teach vocabulary to second language learners.

The need to explore L2 vocabulary acquisition in the Saudi context is crucial to support the rapid reforms, a part of the crucial elements recommended in the 2030 development strategy of the kingdom, to enhance educational standards in Saudi Arabia. Moreover, it has also envisaged improving the outcomes of the English departments as they have failed to yield desired results (Alrabai, 2014, 2016; Alshammari, 2016). The study explores the learning strategies that male and female Saudi learners majoring in English in the Saudi universities follow, and correlate these strategies with their actual vocabulary level.

Vocabulary learning for L2 learners. Until recently, the research on vocabulary language learning has increased, though it was greatly ignored in the past (Al-Masrai \& Milton, 2012). The vocabulary competence

(C) Sahal R. Alshammari. 2020. Published by Igor Sikorsky Kyiv Polytechnic Institute.

This is an Open Access article distributed under the terms of the licence CC BY 4.0 
for L2 learners is essential and fundamental. It is impossible for a second language learner to acquire a language without its sufficient vocabulary. Consequently, L2 learners will not be able to understand a passage unless they understand at least 90\% of its lexical items (Schmitt, 2008, 2010), however, some studies suggest to it $98 \%$ ( $\mathrm{Hu} \&$ Nation, 2000). Some researchers pointed out that learning new vocabulary that led to reading comprehension might be correlated with three factors: vocabulary knowledge, language aptitude, and knowledge \& experience (Hu \& Nation, 2000). For L2 learners, it is more complicated because the learners are monolinguals to a great extent; they have a very limited exposure to English in their schooling because English courses are taught with an objective to learn it as a subject, rather a skill to be acquired, which eventually have reflected further implications as they advance in their specialised courses at their college. Moreover, the differences between the qualitative structure of Arabic and English make it a little difficult for them to acquire at the later stage. In this regard, Stæhr's (2008) study showed that foreign language learners from Denmark who were exposed to seven years of English language learning, but the majority of them could not acquire the most frequent 200-word families in English. Moreover, in the same study, the vocabulary size was found to have a strong association with reading and writing abilities and moderately with listening abilities. Interestingly, the study suggested that the 2000 vocabulary level is the minimum requirement for low-level EFL learners (Stæhr, 2008).

The exposure to language has been supported as an effective strategy in vocabulary learning (Ahmad, 2012). However, the research confirms that gaining a production level from merely exposure is difficult (Schmitt, 2008). Therefore, it is recommended that in EFL learning, instead of incidental learning, explicit learning should be preferred as the primary strategy for vocabulary learning (Stæhr, 2008). This remark is in line with several other studies which confirm the benefits of explicit instruction for adult learners (Berry \& Mason, 2012; De La Paz, 2005; De La Paz \& Graham, 2002; Glaser \& Brunstein, 2007). Moreover, Ullman's model of second language acquisition suggests that lexicon is related to declarative memory which depends on explicit instruction (Ullman, 2004). Therefore, it is recommended to use the incidental vocabulary learning to support the partial knowledge of vocabulary to enhance the vocabulary already learned. The combination of explicit and implicit vocabulary strategies has proved to be effective in enhancing students' vocabulary size, and eventually, in improving their reading comprehension (AlDarayseh \& Tassi., 2014).

Vocabulary learning in the Saudi context. Vocabulary has a strong correlation with all language skills, particularly reading (Baniabdelrahman \& Al-Shumaimeri, 2013). It is observed that poor reading skills of Saudi L2 learners attributed to limited vocabulary (AL-Qahtani, 2016). Moreover, recently Masrai (2019) found that there was a strong correlation between vocabulary acquisition and listening skills of Saudi L2 learners (Masrai, 2019). Undoubtedly, acquiring new vocabulary is a major hurdle for ESL/EFL learners in developing proficiency (Huckin, Haynes, \& Coady, 1993). In the context of Saudi Arabia, it is quite evident because the students who graduate from public schools have an average vocabulary of less than 1000 English words (Alsaif \& Milton, 2012). As a result, there is a huge gap between learners' needs and the nature pedagogy followed for the high school students. Therefore, several attempts have been made recently to advance Saudi EFL learning with effective vocabulary learning strategies; preferential assessment of the relevance of intentional or incidental vocabulary learning in Saudi Arabia is one of several attempts. Ahmad (2012) investigated the type of effective vocabulary learning strategy appropriate in the Saudi context, and the results revealed that the incidental vocabulary learning group outperformed the intentional vocabulary learning group. It contradicts Stæhr's (2008) claim of intentional vocabulary as the most effective one in the Saudi context. Student Teams Achievement Divisions (STAD, hereafter), a learning strategy to improve vocabulary learning for Saudi L2 learners, is a structured learning strategy wherein the students are distributed among small groups to cooperate with one another to achieve a common goal. The results have shown that STAD instructed strategy has a significant influence on vocabulary learning (Ishtiaq, Ali, \& Salem, 2017).

The studies on learning strategies have reported of its usefulness to acquire vocabulary by Saudi (Alhaysony, 2012) and Iranians (Ansarin, Zohrabi, \& Zeynali, 2012) L2 learners. In fact, the learning strategies, particularly the cognitive and metacognitive strategies, have been proved helpful to enhance language proficiency in general for Saudi L2 learners (Alhaison, 2012). This present study is another attempt to find a new dimension of vocabulary acquisition of Saudi L2 learners. It tries to explore differences between the strategies that high and low achievers follow for learning new words and investigate the desired changes to be implemented in the pedagogical approach. This will answer the following questions:

a. Do male and female students have differences in using language learning strategies in learning new vocabulary? 
b. Do language learning strategies affect the vocabulary strength of the learners?
c. Do language learning strategies have effects on academic achievements in vocabulary courses?

\section{Methods}

\section{Participants}

In this descriptive and cross-sectional study, around 85 (39 males \& 46 females) students majoring in English, participated for data collection. All the participants were native Arabic speakers, and their age ranged from 19 to 24 years. The students participated in the study were from first (freshmen) and second years (senior) of their undergraduate programmes in the Department of Language \& Translation at Northern Border University, and they all had completed a course in English vocabulary as part of their programme. For this, the students were asked to bring along their grade sheets of academic achievement to ensure they mark their scores/grades correctly. The present study accounts for the following variable: Dependent (Learners' responses on learning strategies, gender, word families level), Independent (Scores in a specialised course on vocabulary, Scores in CEFR vocabulary test). However, the participants' level in the college is not considered a variable in the study because the learners are privileged to opt for the courses of their choice; those who miss a course in one semester can opt for it later in other semesters. Therefore, it is expected that academic level would not add significant perspectives to the study.

\section{Instruments}

The instrument utilised in this research was one employed by Jones (2006) which was adopted from other researchers (Fan, 2003; Gu \& Johnson, 1996; Nation, 2001a, b; O'Malley \& Chamot, 1990; Oxford, 1990; Schmitt, 2000). Oxford's (1990) Strategy Inventory for Language learning (SILL) version 7.0 was used for the study as the adapted version demonstrated sound reliability and validity indices (Mitits \& Gavriilidou, 2014). The instrument consisted of 50 items related to the students' approach to language learning. The items will be classified under six sections as memory strategies (nine items), cognitive strategies (fourteen items), compensation strategies (six items) meta-cognitive strategies (nine items), affective strategies (six items), and social strategies (six items). The participants were asked to answer each item with a 5-point Likert-style frequency scale as follows: 1) never or rarely true of me, 2) usually not true of me, 3) somewhat true of me, 4) usually true of me, and 5) always or almost always true of me. The positive responses sum up the most preferred strategy $(4 \& 5)$, and the negative responses sum up the least preferred ones $(1 \& 2)$. Neutral cases (3) have not been considered to infer a clear assessment of the most preferred strategies. Firstly, all the items in the questionnaire were translated from English into Arabic and independently back-translated into English by a second translator. The few discrepancies between the original English and the back-translated version resulted in adjustments in the Arabic translation based on direct discussion between the translators. The collected data was analysed using SPSS, version 10.

The inventory consists of 50 items distributed over six parts ('A' to ' $F$ '); these parts can be further classified into the following two broad categories; direct and indirect strategies.

a. Direct strategies include memory strategies (remembering and retrieving vocabulary), cognitive strategies (comprehending and producing text), and compensation strategies (compensating for the lack of knowledge by guessing the meaning through gestures or contexts)

b. Indirect strategies include meta-cognitive strategies (manipulating learning processes), affective strategies (regulating affective state), and social strategies (learning with others).

Descriptive statistics were applied to explore the participants' vocabulary strategy use. For each item on the survey, the frequencies of the responses were calculated in percentages. Also, the means and standard deviations were determined for the 50 strategies listed in the questionnaire. ANOVA carried out to see whether the differences among the mean percentage scores of the six strategies were statistically significant or not; $p$ value of less than 0.05 was considered significant. Descriptive and inferential statistics were employed to analyse the data according to gender. For descriptive statistics, the sample was filtered according to gender and then the percentage scores were calculated so that the males' and females' responses could be compared for each item. The other variables were analysed separately.

A pre-test was conducted to assess their vocabulary stock which was later compared with their final grades as well to check if they reflect their true academic achievements. Students' vocabulary stock would determine their achievement in their courses and eventually their language skill as well. Except the items related to learning strategies, an open-ended item at the end of the questionnaire was also included wherein learners could give suggestions to the teachers and other students. Finally, teachers' opinions regarding the best suited strategies were assessed if they met learners' aspirations and needs. 


\section{Procedure}

The study used two instruments: a survey questionnaire in order to assess learners' learning strategies and a vocabulary test battery to assess learners' vocabulary level. For learning strategies, a standardised (SILL) questionnaire, as developed by Oxford (1990) was used, and for vocabulary level test, Common European Framework Reference (CEFR) was used keeping in view the level of learners in this context. This was ascertained by teachers involved in specialised courses at the undergraduate level at the Northern Border University, Saudi Arabia. For clarity, word has been defined as a base, inflectional as well as derivational forms are considered as separate words (Hirsh \& Nation, 1992).

As per CEFR, there are four milestones in vocabulary learning. 1000 words allow a learner to understand $80 \%$ of the language surrounds him/her, provided the language is not too specialised (Hirsh \& Nation, 1992; Sutarsyah, Nation \& Kennedy, 1994). In theory, $80 \%$ appears a lot but the rest $20 \%$ matters when it comes to deal in real-life situations. Hazenberg and Hulstijn (1996) marked 3000 words needed for a learner to follow $95 \%$ of the most ordinary texts. This applies in general comprehension, as it involves guessing, which is quite different from full comprehension. 5000 words allow one to understand $98 \%$ of ordinary texts as it requires accurate contextual guessing (Hirsh \& Nation, 1992; Laufer, 1997). Up to 10000 words allow learners to understand $99 \%$ of the text and the learners are considered having the vocabulary level as expected for college students. This level is, of course, for the learners who are taught in Englishspeaking countries or have substantial exposure to native speakers or language in use in general. 5000 to 8000 words range is generally considered to be very good for the learners taught in English as a second language background or countries (Hirsh \& Nation, 1992). Therefore, the instrument for the vocabulary test consisted of base forms along with inflicted as well as derivative forms. The present study aimed to explore the vocabulary level of the learners, at least the minimum proficiency expected of them after they complete A2 and B2. The students further move ahead for a specialised course in language skills during their UG programmes. The students chosen for the study had a course devoted completely to vocabulary building exercises and techniques.

\section{Results}

To answer the first question i.e. 'Is there a difference in the level of proficiency in the second language between the male and female students?, ANOVA test was conducted on positive and negative responses to see if there was a significant difference between male and female learners (table $1 \&$ table 2 ).

Table 1. Positive responses for male and female learners

\begin{tabular}{|c|l|l|l|l|l|l|}
\hline Source of Variation & SS & df & MS & F & P-Value & F crit. \\
\hline Between Groups & 299.29 & & 299.29 & 5.16 & 0.025 & 3.93 \\
\hline Within Groups & 5678.02 & 98 & 57.93 & & & \\
\hline Total & 5977.31 & 99 & & & & \\
\hline
\end{tabular}

Table 2. Negative responses for male and female learners

\begin{tabular}{|l|l|l|l|l|l|l|}
\hline Source of Variation & SS & df & MS & F & p-Value & F crit. \\
\hline Between Groups & 75.69 & & 75.69 & 1.58 & 0.21 & 3.93 \\
\hline Within Groups & 4691.22 & 98 & 47.86 & & & \\
\hline Total & 4766.91 & 99 & & & & \\
\hline
\end{tabular}

Since the 'p-Value' i.e. 0.025222264 for positive responses is less than 0.05 and $\mathrm{F}$ Value (i.e. 5.165607025) is greater than $\mathrm{F}$ crit. (i.e. 3.938111078) and the ' $p$-Value' i.e. 0.211580447 for negative responses is more than 0.05 and $\mathrm{F}$ Value (i.e. 1.581170783) is less than F crit. (i.e. 3.938111078), hence, it can be concluded that the mean of positive and negative response of the male and female students are not significantly different from each other i.e. the proficiency level in the second language is the same amongst the male and female students.

To the second question i.e. 'Is there a correlation between second language proficiency and their vocabulary level ?, the vocabulary test results classified students into three categories: 500, 1000, and 2000 vocabulary level. As mentioned earlier, 85 participants took the vocabulary test and the results are shown in Table 3 below. 
Table 3. Learners' Vocabulary level

\begin{tabular}{|l|l|l|l|l|l|l|}
\hline \multicolumn{1}{|c|}{$\begin{array}{c}\text { Vocab. } \\
\text { Level }\end{array}$} & $\begin{array}{c}\text { Total } \\
\text { students }\end{array}$ & $\begin{array}{c}\text { Total } \\
\text { responses }\end{array}$ & $\begin{array}{c}\text { Pos. } \\
\text { responses }\end{array}$ & $\begin{array}{c}\text { \% pos. } \\
\text { responses }\end{array}$ & $\begin{array}{c}\text { Neg. } \\
\text { responses }\end{array}$ & $\begin{array}{c}\text { \% neg. } \\
\text { responses }\end{array}$ \\
\hline Vocab_Level_2000 & 4 & 200 & 143 & $72 \%$ & 20 & $10 \%$ \\
\hline Vocab_Level_1000 & 24 & 1200 & 710 & $59 \%$ & 244 & $20 \%$ \\
\hline Vocab_Level_500 & 57 & 2850 & 1484 & $52 \%$ & 739 & $26 \%$ \\
\hline Total & 85 & 4250 & 2337 & & 1003 & \\
\hline
\end{tabular}

To see whether the proficiency level in the second language is significantly different among the students as per their vocabulary level, ANOVA test was conducted on the positive responses of the students as per their vocabulary level (table 4).

Table 4. Mean positive response of all students

\begin{tabular}{|l|l|l|l|l|l|l|}
\hline $\begin{array}{l}\text { Source of } \\
\text { Variation }\end{array}$ & SS & df & MS & F & P-Value & F crit. \\
\hline $\begin{array}{l}\text { Between } \\
\text { Groups }\end{array}$ & 18125.64 & 2 & 9062.82 & 190.02 & $1.74549 \mathrm{E}-41$ & 3.057 \\
\hline Within Groups & 7010.9 & 147 & 47.69 & & & \\
\hline Total & 25136.54 & 149 & & & & \\
\hline
\end{tabular}

Since the ' $p$-Value' i.e. 1.74549E-41 (1.74549 $\mathrm{x} 10-41)$ is less than 0.05 and $\mathrm{F}$ Value (i.e. 190.02333265) is greater than F crit. (i.e. 3.057620652), hence, it can be concluded that the mean positive response of the students with a different vocabulary level is significantly different from each other i.e. the proficiency level in the second language is significantly different among the students. The students with higher vocabulary level have higher proficiency in the second language than students with lower vocabulary level. The same test was conducted on the negative responses and results are shown in table 5 below.

Table 5. Mean negative response of all students

\begin{tabular}{|l|l|l|l|l|l|l|}
\hline Source of Variation & SS & df & MS & F & P-Value & F crit. \\
\hline Between Groups & 5414.41 & 2 & 2707.20 & 69.28 & $6.35482 \mathrm{E}-22$ & 3.057 \\
\hline Within Groups & 5743.86 & 147 & 39.07 & & & \\
\hline Total & 11158.27 & 149 & & & & \\
\hline
\end{tabular}

Since the ' $p$-Value' i.e. 6.35482E-22 (6.35482 x 10-22) is less than 0.05 and F Value (i.e. 69.28431055) is greater than $\mathrm{F}$ crit. (i.e. 3.057620652), hence, it can be concluded that the mean negative response of the students with a different vocabulary level is significantly different from each other i.e. the proficiency level in the second language is significantly different among the students. The students with higher vocabulary level have higher proficiency in the second language than students with lower vocabulary level.

To address the third question i.e. 'Is there a correlation between student's second language proficiency and their grades in vocabulary course?, ANOVA was conducted using the Microsoft Excel inbuilt function 'AnovaSingle Factor' on the positive responses of the students as per their grade in vocabulary course (table 6).

Table 6. ANOVA-Single Factor on positive responses

\begin{tabular}{|l|l|l|l|l|l|l|}
\hline $\begin{array}{l}\text { Source of } \\
\text { Variation }\end{array}$ & SS & Df & MS & F & P-Value & F crit. \\
\hline $\begin{array}{l}\text { Between } \\
\text { Groups }\end{array}$ & 4613.584 & 4 & 1153.396 & 92.43 & $8.54805 \mathrm{E}-48$ & 2.40 \\
\hline Within Groups & 3057.14 & 245 & 12.47 & & & \\
\hline Total & 7670.724 & 249 & & & & \\
\hline
\end{tabular}

Since the ' $p$-Value' i.e. 8.54805E-48 (8.54805 x 10-48) is less than 0.05 and F Value (i.e. 92.43345741) is greater than F crit. (i.e. 2.40848837), hence, it can be concluded that the mean positive response of the students with different grade in vocabulary course is significantly different from each other i.e. the proficiency level in the second language is significantly different among the students. The students with higher grade (i.e. 'A') in vocabulary course have higher proficiency in the second language than students 
with lower grade (i.e. 'F') in vocabulary course. The same test was conducted on the negative responses of the student as per their grades in the vocabulary course (table 7).

Table 7. ANOVA on negative responses

\begin{tabular}{|l|l|l|l|l|l|l|}
\hline $\begin{array}{l}\text { Source of } \\
\text { Variation }\end{array}$ & SS & df & MS & F & P-Value & F crit. \\
\hline $\begin{array}{l}\text { Between } \\
\text { Groups }\end{array}$ & 882.30 & 4 & 220.57 & 22.73 & $5.46128 \mathrm{E}-16$ & 2.40 \\
\hline $\begin{array}{l}\text { Within } \\
\text { Groups }\end{array}$ & 2376.66 & 245 & 9.70 & & & \\
\hline Total & 3258.96 & 249 & & & & \\
\hline
\end{tabular}

Since the ' $p$-Value' i.e. 5.46128E-16 (5.46128 x 10-16) is less than 0.05 and F Value (i.e. 22.73826294) is greater than F crit. (i.e. 3.057620652), hence, it can be concluded that the mean negative response of the students with different grade in vocabulary course is significantly different from each other i.e. the proficiency level in the second language is significantly different among the students. The students with higher grade (i.e. 'A') in vocabulary course have higher proficiency in the second language than students with lower grades (i.e. 'F') in vocabulary courses. To see whether the students of 2000 vocabulary level and 500 vocabulary level are equally well in all strategies or if they focus more on a particular strategy, and analyse if the difference in proficiency level is due to diverse strategies being followed by the students, ANOVA test was conducted on the positive responses for each strategy as per the vocabulary level.

First, the analysis of positive responses of students of vocabulary level 2000 is shown in table 8; it assesses the differences between the groups as well as within the group (table 9).

Table 8. Positive responses of 2000 vocabulary level group

\begin{tabular}{|l|l|l|l|l|}
\hline Strategies & Count & Sum & Average & Variance \\
\hline Memories & 9 & 28 & 3.11 & 0.61 \\
\hline Cognitive & 14 & 38 & 2.71 & 1.29 \\
\hline Comprehension & 6 & 22 & 3.66 & 0.26 \\
\hline Meta Cognitive & 9 & 26 & 2.88 & 1.36 \\
\hline Affective & 6 & 14 & 2.33 & 1.06 \\
\hline Social & 6 & 15 & 2.5 & 0.3 \\
\hline
\end{tabular}

Table 9. ANOVA test for 2000 vocabulary level group

\begin{tabular}{|l|l|l|l|l|l|l|}
\hline Source of Variation & SS & df & MS & F & P-Value & F crit. \\
\hline Between Groups & 7.21 & 5 & 1.44 & 1.55 & 0.19 & 2.42 \\
\hline Within Groups & 40.80 & 44 & 0.92 & & & \\
\hline Total & 48.02 & 49 & & & & \\
\hline
\end{tabular}

Since the ' $p$-Value' i.e. 0.192196837 is more than 0.05 and $\mathrm{F}$ value (i.e. 1.556851974 ) is less than $\mathrm{F}$ crit. (i.e. 2.42704), hence, it can be concluded that the mean positive response of students of vocabulary level 2000 , corresponding to all strategies is the same i.e. students of vocabulary level 2000 are equally well in all strategies and there is no particular strategy on which they are focusing more as compared to other strategies. Second, the analysis of the positive response of students of vocabulary level 500 is shown in Table 10.

Table 10. Positive responses of 500 vocabulary level group

\begin{tabular}{|l|l|l|l|l|}
\hline Strategy & Count & Sum & Average & Variance \\
\hline Memories & 9 & 228 & 25.33 & 81.25 \\
\hline Cognitive & 14 & 399 & 28.5 & 143.65 \\
\hline Comprehension & 6 & 151 & 25.16 & 120.96 \\
\hline Meta Cognitive & 9 & 359 & 39.88 & 65.86 \\
\hline Affective & 6 & 140 & 23.33 & 139.46 \\
\hline Social & 6 & 207 & 34.5 & 57.1 \\
\hline
\end{tabular}


The statistics show that students of 500 vocabulary level are focusing more on 'Meta-cognitive Strategy', and least on 'Affective Strategy'. Since the ' $p$-Value' i.e. 0.01757863 is less than 0.05 and F Value (i.e. 3.09824762) is more than F crit. (i.e. 2.42704), hence, it can be concluded that the mean positive response of students of vocabulary level 500, corresponding to all strategies are significantly different (table 11).

Table 11. ANOVA for 500 vocabulary level

\begin{tabular}{|l|l|l|l|l|l|l|}
\hline Source of Variation & SS & Df & MS & F & P-Value & F crit. \\
\hline Between Groups & 1630.82 & 5 & 326.16 & 3.09 & 0.01 & 2.42 \\
\hline Within Groups & 4632.05 & 44 & 105.27 & & & \\
\hline Total & 6262.88 & 49 & & & & \\
\hline
\end{tabular}

\section{Discussion}

The study revealed crucial results concerning L2 vocabulary learning in the Saudi context. First, it confirms the similarity of using learning strategies between male and female students. This is in line with Alhaysony's findings (2012), and it is worth mentioning that the participants in both studies are Arabic native speakers from the various regions of Saudi Arabia. Though gender segregation is strictly followed as per the Islamic laws enforced in Saudi educational institutions, both male and female students are exposed to the similar academic environment in terms of academic content as well as the support services; the students do not reflect any significant differences in their vocabulary learning. Gender has not been observed as a crucial factor in EFL learning in any studies conducted so far in Saudi context; this conforms to the recent study conducted on prepositions learning as well (Alshammari, 2019). It contradicts the findings of studies like Mitits (2014), Platsidou and Sipitanou (2015) and Kazamia (2016) which attested gender's significant role in learners' preferences of vocabulary learning strategies for Greek learners; reasons being their different socialisation procedures and their differential processing of brain functions. Though the reasons cited do not sound convincing as there are no studies available accounting for social and psychological needs of the female learners. Various other studies also suggest that gender variable does not reflect any difference in academic performance in Saudi EFL learning (Alshammari, 2016; Ahmad, 2012; Ahmed, 2010; Al-Darayesh \& Tassi, 2014; Alhaisoni, 2012; Alrabai, 2014, 2016; Al-Masrai \& Milton 2012; Elyas \& Picard, 2010; Grami, 2010). The results of the present study revealed that the majority of students fall in the 500vocabulary level, which is a serious problem for students who are majoring English. Out of 85 participants, only four students ranked in the 2000 vocabulary level and 24 in the 1000 vocabulary level. The majority of the participants (57 students) fall in the 500-vocabulary level; one possible reason for such weakness in vocabulary size is because the teachers are not fully aware of the effective influence of learning language strategies on vocabulary size, which has resulted eventually in poor performance of the students (Alnefaie, 2016; Al-Qahtani, 2016; Alsaif \& Milton, 2012). The college students who are majoring in English and are in various levels in their programmes are still in the 500-vocabulary level. Therefore, it is evident that the students in their fourth or fifth semester would not be able to complete their programme with such lexicon size.

Second, the results showed that language learning strategies have benefited the Saudi students with higher vocabulary level or have significant usage of all learning strategies. This is partially in line with Alhaysony, (2012), Ansarin et al., (2012), (Alhaisoni, 2012a) as all these studies specify Cognitive and Metacognitive strategies to be the most favourable strategies for Saudi learners. However, the present study shows that students with high vocabulary level (2000 words) focus equally on all language learning strategies while learning new vocabulary. This indicates that students with higher vocabulary level do not focus on one or two strategies as such; rather all the strategies are equally contributing to their vocabulary buildup. On the other hand, students who are ranked in the 500-vocabulary level focus more on 'Meta-cognitive Strategy' and least on 'Affective Strategy' and the difference between the two strategies is significant at the level 0.05. In a similar study, Thai university students preferred cognitive strategy over other strategies. Interestingly, students with bigger vocabularies showed frequent use of all strategy types. However, though some studies (Alhaisoni, 2012a,b; Ansarin et al., 2012) indicate that Meta-cognitive and Cognitive strategies were the most used among L2 learners, this study indicates that higher vocabulary size L2 learners use all the strategies equally, and the lower vocabulary size L2 learners use the Meta-cognitive strategy more than other strategies. In a similar study on Chinese EFL learners, Ping and Siraj (2012) found that the students lack use deep cognitive and meta-cognitive strategies as oral repetition or dictionary consultation were the most favoured strategies while semantic encoding was the least commonly used. Moreover, in Italian FL context as well, Australian leaners favoured mechanical strategy of repetition over making associations of the contexts (Lawson and Hogben, 1996). This does not show contradiction as it appears to be, this study runs 
statistical test between the positive responses of different strategies to determine if the difference is significant or not. In other words, this study does not depend merely on counting the usage of strategies, but it confirmed the differences by running ANOVA test. Therefore, the study confirmed that learning strategies have a significant influence on vocabulary size, that is, the varied learning strategies the L2 learners use, the bigger vocabulary size he/she will acquire (Sarani and Shirzaei, 2016; Patterson, 2017; Kansizoglu, 2017). It is difficult to generalize statements regarding the most and the least preferred strategy, since studies were conducted on learners of different age group, L2 skill, L1 context. Undeniably, all the strategies conclude that vocabulary learning strategies are effective and improve vocabulary acquisition.

Finally, the students' vocabulary course grades show a significant correlation with their usage of learning strategies. The mean positive response of the students with various grade score in vocabulary course is significantly different from each other $(p<0.05)$. This means that students with a higher grade in vocabulary course use varieties of learning strategies than the students with lower grades. The majority of students who scored 'A' or 'B' grades had higher vocabulary size i.e. 1000, 2000. This adds credibility to the course grades excluding six exceptional cases where students with lower vocabulary size, took higher grade i.e. 'A'. There could be many reasons that may suffice the statement; first, the course in vocabulary is offered in the first semester of the academic programme which the students failed to opt for. Second, it might be that those students were high achievers and their vocabulary size suited their levels i.e. 500 level during their learning in the course, but after that, they failed to further enhance their vocabulary size and achieve A1/B2 level in their academic achievements. Finally, to the researcher's understanding of the studies available so far, only this study correlated students' academic achievements in their specialised courses with their actual vocabulary level, and with their learning strategies, they follow in practice as well. As most of the previous studies have been survey based, and focused mainly on the students' preferences over the available learning strategies, but never focused on their actual level as per their academic achievements. The results of this study revealed that all strategies are helpful depending on the content, context, and on the nature of exposure of the students, it depends on the teachers to make use of all strategies to better suit the learners' needs and proficiency level (Ma, 2009; Masrai, 2019; Al-Masrai \& Milton, 2012; Ishtiaq et al, 2017; Mohammad \& Hazarika, 2016. Ma's (2009) process-oriented vocabulary learning strategies also proposes the stages of acquisition and for each stage learners make use of four strategies (cognitive, metacognitive, social and affective) as per their needs.

Strategy training for students regarding self-regulation of their learning preferences would help them enhance their motivation and self-efficacy (Rasekh and Ranjbary, 2003; Lavasani et al., 2011; Soleimani et al., 2018). The importance of learning strategies is such that some motivational strategies are transferable across varied cultural and linguistic contexts (Cheng and Dornyei, 2007). In a similar line, Sozler (2012) argues that training in the use of effective vocabulary strategies have a positive effect on vocabulary acquisition and thus on improving language competence, whereas low motivation leads to limited strategy use (Ping and Siraj, 2012). The growing role of technology in language education has opened a new dimension for the researchers to further explore vocabulary acquisition in relation to the available strategies and teachers' preparedness to integrate dynamism to language learning and teaching practices (Köse et al., 2016; Hajebi et al., 2018; Reed \& Hooper, 2018; Rossell-Aguilar, 2018; Wang et al., 2015).

\section{Conclusion}

The study confirms the positive and direct influence of language learning strategies on the vocabulary size of Saudi L2 learners. Vocabulary reported to be the foundation of language learning. The study confirms the findings of other related studies on low vocabulary size in Saudi tertiary students though they are majoring English. Very few of them have a higher vocabulary size and are very dynamic in their use of language learning strategies. Therefore, it is crucial that teachers and instructors should encourage their students to use these strategies to build their vocabulary in the L2. The results also show that focusing on one strategy does not improve the vocabulary size; instead focusing equally on all the strategies will guarantee the improvement.

Further studies are needed to assess the nature of strategies and their applicability in various domain of language use because an enhanced strategic competence will certainly aid the process of foreign language acquisition. Developing learners' strategic competence motivate them to enhance their learning experiences. To generalise the current finding, a much bigger sample from all over the kingdom would help developing effective strategies appropriate for the Saudi context. Each strategy may have a differential impact on the learner's learning and to serve his/her needs (developmental, proficiency needs, specific goal-oriented learning, academic etc.). Use of technologies or Information and Communication Technology (ICT) in education has been rapidly evolved recently and has its interference in almost all the areas of education. In 
EFL learning as well as internet-based mobile applications based learning practices have become very common to cater to the learners' autonomy and comfort. Therefore, the nature and modalities of strategies needed in virtual learning platforms desired to be fully explored in detail so that future challenges and needs of EFL learners can be addressed well. Since Saudi Arabia has witnessed an unprecedented expansion in Elearning in the last five years and a very encouraging increase in the number of internet users, developing appropriate strategies or identifying new ones for effective learning is a new field of research in vocabulary acquisition. A study conducted by Oxford \& Gkonou (2018) deserves attention as it discusses the interrelatedness of language, culture and learning strategies. The cultural issues and cultural communication styles can be taught following effective strategies and this study offers ample instances which add new insights to vocabulary acquisition in the EFL context. Studies related to such objectives will further boost the nature of effective strategies to be implemented in classroom settings and elsewhere. Moreover, these will serve as guidelines for the stakeholders involved in decision-making regarding the programmes best suited for the learners.

\section{Acknowledgement}

The researcher gratefully acknowledges the support received in the form of a grant from the Deanship of Scientific Research (DSR), Northern Border University, Arar, KSA for the project "Strategies in vocabulary learning among freshmen and senior EFL learners and its implication on their academic achievements: A contextual study of Saudi Arabia" (\#CMR-2018-3-9-F-7890).

\section{References:}

Ahmad, J. (2012). Intentional vs incidental vocabulary learning. International Association of Research in Foreign Language Education and Applied Linguistics, ELT Research Journal, 1(1), 71-79. Retrieved from http://www.udead.org.tr/journal

Ahmed, A. H. (2010). Students' problems with cohesion and coherence in EFL essay writing in Egypt: different perspectives. Literacy Information and Computer Education Journal (LICEJ), 1(4), $211-221$. https://doi.org/10.20533/licej.2040.2589.2010.0030

Al-Darayseh, A. M., \& Tassi. A. (2014). The impact of using explicit/implicit vocabulary teaching strategies on improving students' vocabulary and reading comprehension. Theory and Practice in Language Studies, 4(6), 1109-1118. https://doi.org/10.4304/tpls.4.6.1109-1118

Al-Masrai, A., \& Milton, J. (2012). The vocabulary knowledge of university students in Saudi Arabia. TESOL Arabia Perspectives, 19(3), 13-19. https://uksacb.org/wp-content/uploads/2013/06/Research-Paper-1.pdf

Al-Qahtani, A. A. (2016). Why do Saudi EFL readers exhibit poor reading abilities? English Language and Literature Studies, 6(1), 1. https://doi.org/10.5539/ells.v6n1p1

Alhaisoni, E. (2012a). Language learning strategy use of Saudi EFL students in an intensive English learning context. Asian Social Science, 8(13), 115-127. https://doi.org/10.5539/ass.v8n13p115

Alhaisoni, E. (2012b). The effect of writing proficiency on writing planning strategy use: a case study of Saudi learners of English. International Journal of Linguistics, 4(3), 78-100. https://doi.org/10.5296/ijl.v4i3.1808

Alhaysony, M. (2012). Vocabulary discovery strategy used by Saudi EFL students in an intensive English language learning context. International Journal of Linguistics, 4(2), 518-535. https://doi.org/10.5296/ijl.v4i2.1724

Alnefaie, S. K. (2016). Teachers' role in the development of EFL curriculum in Saudi Arabia: The marginalised status, Cogent Education, 3(1), https://doi.org/10.1080/2331186X.2016.1240008

Alrabai, F. (2014). A model of foreign language anxiety in the Saudi EFL context. English Language Teaching, 7(7), 82-101. https://doi.org/10.5539/elt.v7n7p82

Alrabai, F. (2016). Factors underlying low achievement of Saudi EFL learners. International Journal of English Linguistics, 6(3), 21. https://doi.org/10.5539/ijel.v6n3p21

Alsaif, A., \& Milton, J. (2012). Vocabulary input from school textbooks as a potential contributor to the small vocabulary uptake gained by English as foreign language learners in Saudi Arabia. Language Learning Journal, 40(1), $21-33$. https://doi.org/10.1080/09571736.2012.658221

Alshammari, S. R. (2016). Improving Saudi English learners' second-language acquisition in argumentative writing through selfregulated strategy development. Ph.D. dissertation, University of Kansas - Kansas. Retrieved from https://kuscholarworks.ku.edu/bitstream/handle/1808/21995/ Alshammari_ku_0099D_14579_DATA_1.pdf?sequence=1\&isAllowed=y

Alshammari, S. (2019). Aprendizaje basado en datos y enseñanza de preposiciones en ESL: un estudio de estudiantes árabes (Data driven learning and teaching of prepositions in ESL: A study of Arab learners). IJERI, $153-168$. https://www.upo.es/revistas/index.php/IJERI/article/download/3809/3463/12390

Ansarin, A. A., Zohrabi, M., \& Zeynali, S. (2012). Language learning strategies and vocabulary size of Iranian EFL learners. Theory and Practice in Language Studies, 2(9), 1841-1848. https://doi.org/10.4304/tpls.2.9.1841-1848

Baniabdelrahman, A. A., \& Al-Shumaimeri, Y. (2013). Strategies used by Saudi EFL students to determine the meaning of English words. English Language Teaching, 7(1), 75-92. https://doi.org/10.5539/elt.v7n1p75

Berry, A. B., \& Mason, L. H. (2012). The effects of self-regulated strategy development on the writing of expository essays for adults with written expression difficulties: Preparing for the GED. Remedial and Special Education, 33(2), $124-136$. https://doi.org/10.1177/0741932510375469

Bonk, W. J. (2000). Second language lexical knowledge and listening comprehension. International Journal of Listening, 14(1), 1431. https://doi.org/10.1080/10904018.2000.10499033

Cheng, Hsing-Fu \& Dörnyei, Zoltán. (2007). The Use of Motivational Strategies in Language Instruction: The Case of EFL Teaching 
in Taiwan. Innovation in Language Learning and Teaching, 1, 153-174. https://doi.org/10.2167/illt048.0

De La Paz, S. (2005). Effects of historical reasoning instruction and writing strategy mastery in culturally and academically diverse middle school classrooms. Journal of Educational Psychology, 97(2), 139-156. https://doi.org/10.1037/00220663.97.2.139

De La Paz, S., \& Graham, S. (2002). Explicitly teaching strategies, skills, and knowledge: writing instruction in middle school classrooms. Journal of Educational Psychology, 94(4), 687-698. https://doi.org/10.1037/0022-0663.94.4.687

Doushaq, H. H. (1986). An investigation into stylistic errors of Arab students learning English for academic purposes. English for Specific Purposes, 5(1), 27-39. https://doi.org/10.1016/0889-4906(86)90005-0

Elyas, T., \& Picard, M. (2010). Saudi Arabian educational history: impacts on English language teaching. Education, Business and Society: Contemporary Middle Eastern Issues, 3(2), 136-145. https://doi.org/10.1108/17537981011047961

Fan, Y. M. (2003). Frequency of use, perceived usefulness, and actual usefulness of second language vocabulary strategies: A study of Hong Kong learners. The Modern Language Journal, 87(2), 222-241.

Glaser, C., \& Brunstein, J. C. (2007). Improving fourth-grade students' composition skills: effects of strategy instruction and selfregulation procedures. Journal of Educational Psychology, 99(2), 297-310. https://doi.org/10.1037/0022-0663.99.2.297

Grami, G. M. A. (2010). The effects of integrating peer feedback into the university-level ESL writing curriculum: A comparative study in a Saudi context. Ph.D. dissertation, University of Newcastle-upon-Tyne.

Gu, Y., \& Johnson, R. K. .(1996). Vocabulary learning strategies and language learning out- comes. Language Learning, 46(4), 643-679.

Hajebi, M., SeddiQ. T., Fahandezh, F., \& Salari, H. (2018). The role of web-based language teaching on vocabulary retention of adult pre-intermediate. Journal of Language Teaching and Research, 9(2), 372-378.

Hashim, N. (1996). English syntactic errors by Arabic speaking learners: reviewed. Retrieved from https://files.eric.ed.gov/fulltext/ED423660.pdf (ERIC)

Hazenberg, S., \& Hulstijn, J. H. (1996). Defining a minimal receptive second-language vocabulary for non-native university students: an empirical investigation. Applied Linguistics, 17(2), 145-163. https://doi.org/10.1093/applin/17.2.145

Hirsh, D., \& Nation, P. (1992). What vocabulary size is needed to read unsimplified texts for pleasure?. Reading in a Foreign Language, 8(2), 689-699. https://doi.org/10.26686/wgtn.12560417.v1

Hu, M., \& Nation, P. (2000). Unknown vocabulary density and reading comprehension. Reading in a Foreign Language, 13(1), 403430. https://doi.org/10.26686/wgtn.12560354.v1

Huckin, T., Haynes, M., \& Coady, J. (Eds.). (1993). Second language reading and vocabulary learning. Norwood, N.J.: Ablex Publishing Corporation.

Ishtiaq, M., Ali, Z., \& Salem, M. (2017). An experimental study of the effect of Student Teams Achievement Divisions (STAD) on vocabulary learning of EFL adult learners. Arab World English Journal, 8(3), 356-375. https://doi.org/10.24093/awej/vol8no3.23

Jones, R. (2006). Vocabulary learning strategy use among tertiary students in the United Arab Emirates. Perspective, 14(1), 4-8.

Kansizoğlu, H. B. (2017). The comparison of Vocabulary Teaching Methods in terms of their effect on vocabulary development: A Meta-Analytic Review. International Online Journal of Educational Sciences (IOJES), 9(3), 821-841. https://doi.org/10.15345/iojes.2017.03.017

Kazamia, V. (2016). Gender and age impact on language learning strategy use: A research on Greek EFL learners. In Z. Gavriilidou \& K. Petrogiannis (eds), Language Learning Strategies in the Greek setting: Research outcomes of a largescale project (pp. 76-100). Kavala: Saita Publications.

Köse, T. Çimen, E. \& Mede, E. (2016). Perceptions of EFL learners about using an online tool for vocabulary learning in EFL classrooms: A pilot Project in Turkey. International Conference Teaching and Learning English as an Additional Language GlobELT 2016, Nisan 2016, Türkiye: Antalya, Procedia - Social and Behavioral Sciences, 232, $362-372$. https://doi.org/10.1016/j.sbspro.2016.10.051

Laufer, B. (1997). The Lexical Plight in Second Language Reading: Words You Don't Know, Words You Think You Know and Words You Can't Guess. In J. Coady, \& T. Huckin (Eds.) Second Language Vocabulary Acquisition: A Rationale for Pedagogy (pp. 20-34). Cambridge: Cambridge University Press.

Lavasani, Masoud \& Mirhosseini, Fatemeh \& Hejazi, Elaheh \& Davoodi, Maryam. (2011). The Effect of Self-regulation Learning Strategies Training on the Academic Motivation and Self-efficacy. Procedia - Social and Behavioral Sciences, 29, 627632. doi:10.1016/j.sbspro.2011.11.285.

Lawson, M. J., \& Hogben, D. (1996). The vocabulary-learning strategies of foreign-language students. Language Learning, 46(1), 101-135. https://doi.org/10.1111/j.1467-1770.1996.tb00642.x

Ma, Qing. 2009. Second language vocabulary acquisition. Bern: Peter Lang.

Masrai, A. (2019). Exploring the impact of individual differences in aural vocabulary knowledge, written vocabulary knowledge and working memory capacity on explaining L2 learners' listening comprehension. Applied Linguistics Review. https://doi.org/10.1515/applirev-2018-0106

Mitits, L. (2014). Language learning strategy use by early adolescent monolingual EFL and multilingual EFL/L2 Greek learners in the Greek educational context. PhD dissertation, Department of Greek Philology, Democritus University of Thrace, Greece, Published in Saita Publications available at http://www.saitabooks.eu/2015/03/ebook.147.html

Mitits, L. \& Gavriilidou, Z. (2014). Effects of gender, age, proficiency level and motivation differences on monolingual and multilingual students' language learning strategies. Studies in Greek linguistics, Proceedings of the Annual Meeting of the Department of Linguistics (pp.285-299). School of Philology, Faculty of Philology,

Mohamed, M., \& Mahmoud, A. (2014). The effectiveness of using the cooperative language learning approach to enhance EFL writing skills among Saudi university students. Journal of Language Teaching and Research, 5(3), 616-625. https://doi.org/10.4304/jltr.5.3.616-625

Mohammad, T., \& Hazarika, Z. (2016). Difficulties of learning EFL in KSA: writing skills in context. International Journal of English Linguistics, 6(3), 105. https://doi.org/10.5539/ijel.v6n3p105

Nation, I. S. P. (2001a). How many high frequency words are there in English. Language, Learning and Literature: Studies 
presented to Hakan Ringbom, 4, 167-181. Abo Akademi University, Abo: English Department Publications.

Nation, I. S. P. (2001b). Learning vocabulary in another language. Cambridge, UK: CUP.

O' Malley, J. M., \& Chamot, A. U. (1990). Learning strategies in second language acquisition. Cambridge: Cambridge University Press.

Oxford, R. L. (1990). Language learning strategies: What every teacher should know. Boston, MA: Heinle.

Oxford, R. L., \& Gkonou, C. (2018). Interwoven: culture, language, and learning strategies. SSLLT, 8 (2), 403-426. https://doi.org/ 10.14746/ssllt.2018.8.2.10

Patterson, D. (2017). Vocabulary-building activities for the EFL classroom. $13^{\text {th }} \& 14^{\text {th }}$ Annual LaoTESOL Conference Proceedings: Selected Papers (2016-2017) (pp. 164-171) National University of Laos, Vientiane, Laos.

Ping, A. M. \& Siraj, S. (2012). Exploring selfregulatory strategies for vocabulary learning among Chinese EFL learners. Procedia Social and Behavioral Sciences, 47, 1211-1215. https://doi.org/10.1016/j.sbspro.2012.06.802

Platsidou, M., \& Sipitanou, A. (2015). Exploring relationships with grade level, gender and language proficiency in the foreign language learning strategy use of children and early adolescents. International Journal of Research Studies in Language Learning, 4(1), 76-101.

Rababah, G. (2002). Communication problems facing Arab learners of English. Journal of Language and Learning, 3(1), 180-197.

Rasekh, Z. E., \& Ranjbary, R. (2003). Metacognitive strategy training for vocabulary learning. TESL-EJ, 7(2), A-5. https://www.teslej.org/ej26/a5.html

Reed, J. T. \& Hooper, D. (2018). Student perceptions of mobile learning of high frequency vocabulary using the "Memrise" app. The Journal of Kanda University of International Studies, 30, 351- 371. http://id.nii.ac.jp/1092/00001486/

Rossell-Aguilar, F. (2018). Autonomous language learning through a mobile application: A user evaluation of the Busuu app. Computer Assisted Language Learning, 31(8), 854-881.

Sarani, A., \& Shirzaei, H. (2016). A comparative study of vocabulary learning strategies employed by Iranian undergraduate and postgraduate EFL learners with a focus on motivation. Indonesian Journal of EFL and Lingusitics, 1(1), 33-45. http://dx.doi.org/10.21462/ijefll.v1i1.2

Schmitt, N. (2010). Researching vocabulary: A vocabulary research manual. London: Palgrave Macmillan.

Schmitt, N. (2008). Review article: Instructed second language vocabulary learning. Language Teaching Research, 12(3), 329363. https://doi.org/10.1177/1362168808089921

Schmitt, N. (2000). Vocabulary in language teaching. Cambridge: Cambridge University Press.

Stæhr, L. S. (2008). Vocabulary size and the skills of listening, reading and writing. Language Learning Journal, 36(2), 139-152. https://doi.org/10.1080/09571730802389975

Soleimani, H., Aghayani, B., \& Ashari, N. (2018). The relationship among EFL learners' self-regulation, locus of control, and preference for vocabulary acquisition. Applied Linguistics Research Journal, 2(1), 14-24. https://doi.org/10.14744/alrj.2018.08208

Sozler, S. (2012). The Effect of Memory Strategy Training on Vocabulary Development of Austrian Secondary School Students. Procedia - Social and Behavioral Sciences, 46, 1348-1352. https://doi.org/10.1016/j.sbspro.2012.05.300

Sutarsyah, C., Nation, P., \& Kennedy, G. (1994). How Useful Is Eap Vocabulary for Esp? a Corpus Based Case Study. RELC Journal, 25(2), 34-50. https://doi.org/10.1177/003368829402500203

Ullman, M. T. (2004). Contributions of memory circuits to language: the declarative/procedural model. Cognition, 92(1-2), 231-270. https://doi.org/10.1016/j.cognition.2003.10.008

Wang, B.-T., Teng, C.-W., \& Chen, H.-T. (2015). Using iPad to facilitate English vocabulary learning. International Journal of Information and Educational Technology, 5(2), 100-104. https://doi.org/10.7763/ijiet.2015.v5.484

Received: May 11, 2020

Accepted: November 20, 2020 